\title{
Vol. 5
}

1989
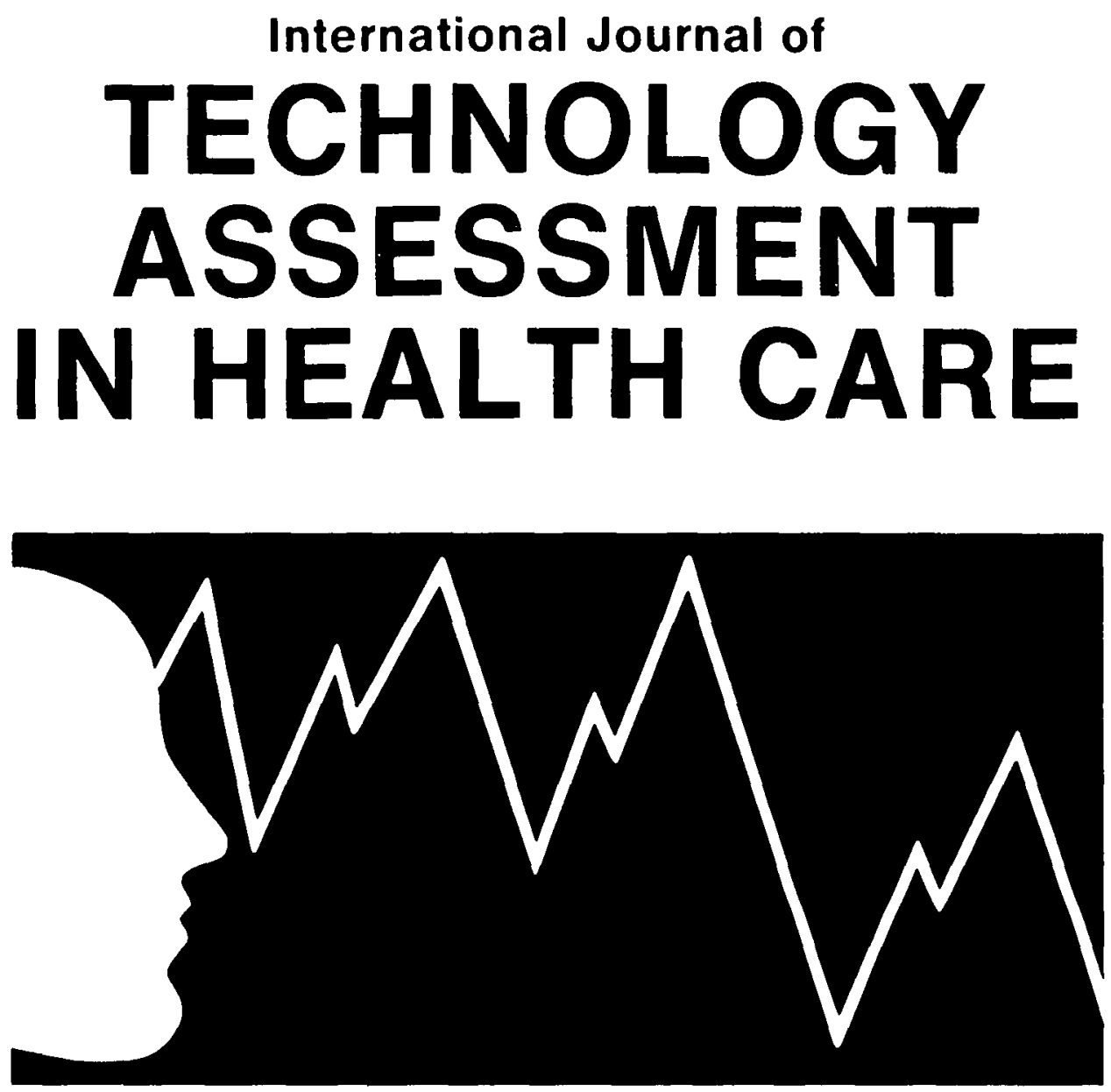

Cambridge University Press 
Published by the Press Syndicate of the University of Cambridge The Edinburgh Building, Shaftesbury Road, Cambridge CB2 2RU 40 West 20th Street, New York, NY 10011, USA

10 Stamford Road, Oakleigh, Melbourne 3166, Australia

c) Copyright 1989 by Cambridge University Press

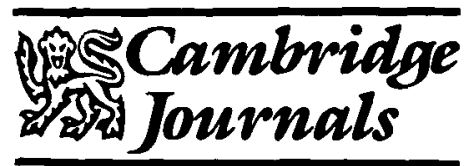

Printed in the United States of America 
Ballard, David J., Khandheria, Bijoy K., Tajik, A. Jamil, Seward, James B., Weber, Vernon P., and Melton, L. Joseph, III. POPULATION-BASED STUDY OF ECHOCARDIOGRAPHY: TIME TRENDS IN UTILIZATION AND DIAGNOSTIC PROFILE OF AN EVOLVING TECHNOLOGY, 1975-1987, 249.

Barry, Michael J. See Richter, 53.

Battista, Renaldo N. INNOVATION AND DIFFUSION OF HEALTH-RELATED TECHNOLOGIES: A CONCEPTUAL FRAMEWORK, 227.

Baum, Michael. ASSESSMENT, ETHICS, AND THE RANDOMIZED CONTROLLED TRIAL, 305; LIMITATIONS OF NONSCIENCE IN SURGICAL EPISTEMOLOGY: THE SECOND-LOOK LAPAROTOMY, 381. See Bunker, 315; Ebbs, 391; Houghton, 415.

Bernstein, David P. See Kaufman, 631.

Black, Douglas. EXPENSIVE MEDICAL AND SURGICAL TECHNOLOGY, 308.

Bloom, Bernard S., and Gessner, Urs. LONG-TERM TECHNOLOGY ASSESSMENT: MORTALITY, HOSPITALIZATION, AND WORK LOSS DUE TO PEPTIC ULCER AND GASTRITIS/DUODENITIS IN THE FEDERAL REPUBLIC OF GERMANY, 215.

Blumenthal, David, and Zeckhauser, Richard. GENETIC DIAGNOSIS: IMPLICATIONS FOR MEDICAL PRACTICE, 579.

Borgquist, Lars. See Persson, 31.

Bretaudierre, Jean-Pierre. See Kaufman, 631.

Bunker, John P., and Baum, Michael. PREFACE: TECHNOLOGY ASSESSMENT AND SURGICAL POLICY, 315.

Burdick, Elisabeth. See Mosteller, 123.

Burton, Benjamin T. See Foster, 173.

Calltorp, Johan, and Smedby, Björn. TECHNOLOGY ASSESSMENT ACTIVITIES IN SWEDEN, 263.

Chalmers, Thomas C., Hewitt, Peg, Reitman, Dinah, and Sacks, Henry S. SELECTION AND EVALUATION OF EMPIRICAL RESEARCH IN TECHNOLOGY ASSESSMENT, 521.

Clarke, John R. APPENDICITIS: THE COMPUTER AS A DIAGNOSTIC TOOL, 371.

Cohen, J. APPROPRIATE TECHNOLOGY IN PRIMARY HEALTH CARE: EVOLU. TION AND MEANING OF WHO'S CONCEPT, 103.

Detsky, Allan S. See Goel, 183.

Ebbs, Stephen R., Fallowfield, Lesley J., Fraser, Simon C.A., and Baum, Michael.

TREATMENT OUTCOMES AND QUALITY OF LIFE, 391.

Eddy, David M. INTRODUCTION, 483; SELECTING TECHNOLOGIES FOR ASSESSMENT, 485.

Fagnani, Francis. See Weill, 144.

Fallowfield, Lesley J. See Ebbs, 391.

Feeny, David. See Torrence, 559.

Foster, Willis R., and Burton, Benjamin T. TECHNOLOGY ASSESSMENT APPLIED

TO LIVER TRANSPLANTATION IN ADULTS, 173.

Fraser, Simon C.A. See Ebbs, 391.

Gelber, Richard D., and Goldhirsch, A. COMPARISON OF ADJUVANT THERAPIES USING QUALITY-OF-LIFE CONSIDERATIONS, 401.

Gessner, Urs. See Bloom, 215.

Gildenberg, Philip L. See Kaufman, 631.

Goel, Vivek, and Detsky, Allan S. A COST-UTILITY ANALYSIS OF PREOPERATIVE TOTAL PARENTERAL NUTRITION, 183.

Goldhirsch, A. See Gelber, 401. 
Goodson, John D. See Richter, 53.

Gross, Paul F. TECHNOLOGY ASSESSMENT IN HEALTH CARE IN AUSTRALIA, 137.

Hakama, Matti, Karjalainen, Sakari, and Hakulinen, Timo. OUTCOME-BASED EQUITY IN THE TREATMENT OF COLON CANCER PATIENTS IN FINLAND, 619.

Hakulinen, Timo. See Hakama, 619.

Harvey, John D. TOWARDS A USER-FRIENDLY FUTURE: THE IMPACT OF INFORMATION TECHNOLOGY WITHIN PRIMARY HEALTH CARE, 79.

Hewitt, Peg. See Chalmers, 521.

Horder, John, and Metcalfe, David. REQUIREMENTS FOR TECHNOLOGY: AS SEEN BY PROVIDERS OF PRIMARY HEALTH CARE, 91.

Houghton, Joan, and Baum, Michael. ADJUVANT RADIOTHERAPY IN BREAST CANCER: CONSIDERATION OF COST-BENEFITS IN RELATION TO THE CRC (KING'S/CAMBRIDGE) TRIAL, 415.

Howard, Ronald A. MICRORISKS FOR MEDICAL DECISION ANALYSIS, 357.

Hoyle, M. Frances, and Jamieson, Lisa N. USE OF SLOWSCAN TECHNOLOGY IN THE NORTH SLOPE BOROUGH TELEHEALTH PROJECT, 63.

Jaeschke, Roman, and Sackett, David L. RESEARCH METHODS FOR OBTAINING PRIMARY EVIDENCE, 503.

Jamieson, Lisa N. See Hoyle, 63.

Jennett, Bryan. SURGERY TO PREVENT STROKE: HIGH HOPES AND DEEP DISAPPOINTMENT, 443.

Jersild, P.C. ON INGENUITY AND SEDUCTION, 169.

Jonsson, Egon, and Reiser, Stanley J. INTRODUCTION, 7.

Karjalainen, Sakari. See Hakama, 619.

Kaufman, Howard H., Bretaudierre, Jean-Pierre, Rowlands, Brian J., Stein, Debra K., Bernstein, David P., Wagner, Karen A., and Gildenberg, Philip L. HEAD INJURY: VARIABILITY OF COURSE AND PRESENCE OF CONFOUNDING FACTORS, 631.

Kent, Daniel J. See Larson, 195.

Khandheria, Bijoy K. See Ballard, 249.

Kolker, Aliza. ADVANCES IN PRENATAL DIAGNOSIS: SOCIAL-PSYCHOLOGICAL AND POLICY ISSUES, 601.

Larson, Eric B., and Kent, Daniel L. THE RELEVANCE OF SOCIOECONOMIC AND HEALTH POLICY ISSUES TO CLINICAL RESEARCH: THE CASE OF MRI AND NEURORADIOLOGY, 195.

LeFaure, Christian. See Weill, 144.

Lehtinen, Ville, Panelius, Martin, and Tienari, Pekka. FINNISH CONSENSUS DEVELOPMENT CONFERENCE ON THE TREATMENT OF SCHIZOPHRENIA, 269.

Lilford, Richard J. EVALUATING NEW TREATMENTS AND DIAGNOSTIC TECHNOLOGIES IN OBSTETRICS: PRACTICAL PROBLEMS, ETHICS, AND SOLUTIONS, 459.

Lorch, Stephen. TECHNOLOGY AND THE WORK OF THE DOCTOR OUTSIDE THE HOSPITAL, 43.

MacRae, Kenneth D. PRAGMATIC VERSUS EXPLANATORY TRIALS, 333.

McKneally, Martin. See McPeek, 317.

McPeek, Bucknam, Mosteller, Frederick, and McKneally, Martin. RANDOMIZED CLINICAL TRIALS IN SURGERY, 317.

Melton, L. Joseph, III. See Ballard, 249.

Metcalfe, David. See Horder, 91.

Michaeli, Dan. CRISIS AND CHALLENGES IN THE HEALTH CARE SYSTEM: A PERSONAL POINT OF VIEW, 1.

Mosteller, Frederick. See McPeek, 317. 
Mosteller, Frederick, and Burdick, Elisabeth. CURRENT ISSUES IN HEALTH CARE TECHNOLOGY ASSESSMENT, 123.

Novaes, Simone B. GIVING, RECEIVING, REPAYING: GAMETE DONORS AND DONOR POLICIES IN REPRODUCTIVE MEDICINE, 639.

Panelius, Martin. See Lehtinen, 269.

Persson, Jan, and Borgquist, Lars. DIFFUSION OF MEDICAL DEVICES IN PRIMARY HEALTH CARE IN SWEDEN, 31.

Preston, Thomas A. ASSESSMENT OF CORONARY BYPASS SURGERY AND PERCUTANEOUS TRANSLUMINAL CORONARY ANGIOPLASTY, 431.

Ramirez-Sanchez, Teresita de Jesus. See Sanchez-Carrillo, 659.

Reiser, Stanley J. See Jonsson, 7.

Reitman, Dinah. See Chalmers, 521.

Richter, James M., Goodson, John D., Barry, Michael J., and Treadway, Katherine K. MEDICAL DIAGNOSTIC TECHNOLOGY IN THE HOME, 53.

Roe, Wayne I. See Young, 9.

Roos, Leslie L. NONEXPERIMENTAL DATA SYSTEMS IN SURGERY, 341.

Rowlands, Brian J. See Kaufman, 631.

Sackett, David L. See Jaeschke, 503.

Sacks, Henry S. See Chalmers, 521.

Sanchez-Carrillo, Constanza I., Ramirez-Sanchez, Teresita de Jesus, Zambrana-Castañeda, Marcela, and Selwyn, Beatrice J. TEST OF A NONINVASIVE INSTRUMENT FOR MEASURING HEMOGLOBIN CONCENTRATION, 659.

Selwyn, Beatrice J. See Sanchez-Carrillo, 659.

Seward, James B. See Ballard, 249.

Sjönell, Göran. THE IMPACT OF NEW TECHNOLOGIES IN PRIMARY HEALTH CARE, 73.

Skrabanek, Petr. MASS MAMMOGRAPHY: THE TIME FOR REAPPRAISAL, 423.

Smedby, Björn, See Calltorp, 263.

Stein, Debra K. See Kaufman, 631.

Stoeckle, John D. PRIMARY CARE AND DIAGNOSTIC TESTING OUTSIDE THE HOSPITAL, 21.

Strauss, Michael J. See Young, 9.

Tajik, A. Jamil. See Ballard, 249.

Tienari, Pekka. See Lehtinen, 269.

Torrance, George W., and Feeny, David. UTILITIES AND QUALITY-ADJUSTED LIFE YEARS, 559.

Treadway, Katherine K. See Richter, 53.

Tymstra, Tjeerd. THE IMPERATIVE CHARACTER OF MEDICAL TECHNOLOGY AND THE MEANING OF "ANTICIPATED DECISION REGRET," 207.

Tyson, Ted R. SYNERGISM IN TECHNOLOGY ASSESSMENT, 477.

Vang, Johannes. TECHNOLOGY ASSESSMENT AND PRIMARY HEALTH CARE IN EUROPE: ISSUES AND PROBLEMS, 111.

Wagner, Karen A. See Kaufman, 631.

Weber, Vernon P. See Ballard, 249.

Weill, Caroline, Fagnani, Francis, and LeFaure, Christian. THE ASSESSMENT OF MEDICAL TECHNOLOGY: THE CASE OF FRANCE, 144.

Wolpert, Robert L. ELICITING AND COMBINING SUBJECTIVE JUDGMENTS ABOUT UNCERTAINTY, 537. 
Young, Donald A., Roe, Wayne I., and Strauss, Michael J. TECHNOLOGY AND PRIMARY CARE IN THE UNITED STATES: A CHALLENGE FOR TECHNOLOGY ASSESSMENT, 9.

Zambrana-Castañeda, Marcela. See Sanchez-Carrillo, 659.

Zeckhauser, Richard. See Blumenthal, 579. 


\section{International Journal of Technology Assessment in Health Care}

\section{Instructions for Contributors}

The editors welcome submissions of articles which deal with the wide range of topics related to technology assessment in health care - policy, practice, diffusion, economics, ethics, law, and social and cultural perspectives. Authors should send three copies of their manuscript and reserve one copy for their use in checking proofs. Articles must be in English. Spelling, capitalization, and punctuation must be consistent within each article and conform with the 13th Edition of The Chicago Manual of Style (University of Chicago Press). Articles and correspondence should be sent to: Stanley J. Reiser, The University of Texas Health Science Center at Houston, P.O. Box 20708, Houston, Texas 77225, U.S.A.; or Egon Jonsson, The Karolinska Institute and the Swedish Council on Technology Assessment in Health Care, P.O. Box 16158, 10324 Stockholm, Sweden.

Permissions. Submission of an article implies that it has not been published elsewhere. Authors are responsible for obtaining written permission to publish material for which they do not own the copyright. Contributors will be asked to assign their copyrights, on certain conditions, to Cambridge University Press.

Preparation of Manuscript. The entire manuscript, including all notes and references, must be typed, double-spaced on $81 / 2 \times 11$ inch or A4 paper, leaving wide margins for copyediting. Manuscript pages should be numbered consecutively (including the cover sheet). Manuscripts should be arranged as follows: (1) cover sheet, (2) title page, (3) abstract, (4) acknowledgments, (5) text, (6) notes, (7) references, (8) appendix, (9) tables with titles, (10) figures with captions. The cover sheet should list the article title (in capital letters), a name and complete mailing address to which proofs should be sent, the name and telephone number of the lead author, and a short title ( 50 characters or less) for the running head. The title page should list the article title (in capital letters) and all authors' names and affiliations, as they should appear for publication. The abstract cannot exceed 50 words. Any notes to the title or authors and any acknowledgments should be noted on a separate sheet and placed after the abstract.

References and notes. Bibliographic citations in the text are indicated by in-line numbers in parentheses; the numbers in the text correspond to numbers that directly precede each reference.

Text

". . Jones and Smith (1) maintained that ..."

If more than one reference is cited at a specific place in the text, semicolons should separate each reference number; if page numbers are included, commas should separate each reference number from its page number(s).

Multiple citations without page numbers

... this system has been dealt with at length in the literature $(1 ; 3 ; 12 ; 14)$.

Multiple citation with page numbers

... This system has been dealt with at length $(1,1-10 ; 3,5 ; 12,25-57 ; 14,102-146)$.

Reference (Book)

1. Jones, A. B., \& Smith, J. K. Computer diagnosis and results. New York: Penta Publishers, 1978.

Reference (Journal)

1. Jones, A. B., \& Smith, J. K. The relationship between health needs, the hospital and the patient. Journal of Chronic Diseases, 1985, 32, 310-12.

Reference (Article in edited work)

1. Jones, A. B., \& Smith, J. K. The diagnostic process. In R. Brown \& T. Wilson (eds.), New technology and its medical consequences, vol. 1. New York: Apple Publishers, 1972, 101-34.

The reference list must be in alphabetical order. Titles of journals should not be abbreviated.

When more than a simple source citation is called for, endnotes may be used. Notes should be numbered consecutively throughout the text and typed together on a separate page preceding the reference section. Source citations within notes follow the same parameters of style as citations in text.

Tables and figures. Tables and figures should be numbered consecutively and appear as one unit after the reference section. All tables must be titled; all figures must be captioned. All tables and figures must have at least one text reference, using the following form: "For a different view of this matter, see Table 1 and Figure 3." Table footnotes appear directly after the table body; table source notes follow the footnotes. Figures should be drawn by a professional artist or computer-generated on a Laser printer. The publisher cannot redraw any figure unless the author pays for the cost of such work. All figures should remain legible at a $50 \%$ reduction in size.

Copyediting and proofreading. The publishers reserve the right to copyedit and proofread all articles accepted for publication, but the lead author will be asked to review the copyediting if changes have been substantial. Page proof of a Special Section or General article will be sent to the lead author for correction of typographical errors only.

Offprints. The lead author of a Special Section or General article will receive 25 offprints of his/her article free of charge; additional numbers may be purchased if ordered at proof stage. 


\title{
INTERNATIONAL JOURNAL OF TECHNOLOGY ASSESSMENT IN HEALTH CARE
}

\section{Featured Special Sections and Guest Editors in Forthcoming Issues}

\author{
Measuring Health Care Effectiveness: The Use of Large \\ Data Bases for Technology and Quality Assessments \\ Ruth S. Hanft, The George Washington University, U.S.A. \\ Jane E. Sisk, Office of Technology Assessment, U.S.A. \\ Catherine C. White, The George Washington University, U.S.A.
}

\section{Assessing the Technology of Dentistry}

Lars E. A. Folke, University of Lund, Sweden

Paul Goldhaber, Harvard School of Dental Medicine, U.S.A.

\section{The Technology of Prevention}

Felix F. Gutzwiller, University of Laussanne, Switzerland Jeffrey Koplan, Centers for Disease Control, U.S.A.

\section{Technology and Disability}

John Hutton, University of York, England

Jan Pearson, Linköping University, Sweden

The Use and Abuse of Routine, Low Cost Technology

Johannes Vang, World Health Organization, Denmark

Industry and the Generation of Technology

Jerome Grossman, New England Medical Center Hospitals, U.S.A.

Judith Kurland, Department of Health and Hospitals, Boston, U.S.A.

\section{Assessing the Technology of Physical Therapy}

Margareta af Klinteberg, Gnesta Primary Health Center, Sweden

Nancy T. Watts, Massachusetts General Hospital, Boston, U.S.A.

Obstetric Technology: A Future Perspective

Miriam Orleans, University of Colorado Health Sciences Center, U.S.A.

Elina Hemminki, University of Helsinki, Finland

\section{Technology and Ethics}

Arthur L. Caplan, University of Minnesota, U.S.A.

James F. Childress, University of Virginia, U.S.A.

Henrik R. Wulff, Herlev University Hospital, Denmark

Genetic Technology and Health Care

Frederick C. Robbins, Case Western Reserve University, U.S.A.

\section{The Person-Machine Relationship in Health Care}

Yadin David, Texas Children's Hospital, U.S.A.

The Assessment of Psychiatry

Lawrence R. Tancredi, University of Texas Health Science Center at Houston, U.S.A.

\section{Assessing Intensive Care}

Bernard S. Bloom, University of Pennsylvania, U.S.A.

Dag Lundberg, University of Lund, Sweden

\section{Technology and the Consumer}

Per Buch Andreasen, Gentofte University Hospital, Denmark

Ralph Crawshaw, Private Practitioner, Oregon, U.S.A.

Barbara Stocking, King's Fund College, U.K.

\section{Orphan Technologies}

Judith L. Wagner, Office of Technology Assessment, U.S.A.

Cambridge University Press

The Edinburgh Building, Shaftesbury Road, Cambridge CB2 2RU, England

40 West 20th Street, New York, NY 10011, U.S.A.

10 Stamford Road, Oakleigh, Melbourne 3166, Australia 